\title{
Immunomodulatory and immunostimulatory effects of some bisbenzoxazole derivatives on lipopolysaccharide stimulated mammalian macrophages
}

\author{
Furkan AYAZ $1 * \mathbb{D}$, Qadar Ahmed ISSE 1 (D), Rusmeenee KHEEREE 1 (D), Ronak Haj ERSAN 2 (D), \\ Öztekin ALGÜL 2 * (D) \\ 1 Mersin University, Biotechnology Department, 33110, Mersin, Turkey \\ 2 Mersin University, Faculty of Pharmacy, Department of Pharmaceutical Chemistry, 33169, Mersin, Turkey \\ * Corresponding authors: furkanayaz@mersin.edu.tr (F.A.); oztekinalgul@mersin.edu.tr (Ö.A.). Tel. +90-324-361-00 01.
}

Received: 22 January 2019 / Revised: 26 May 2019 / Accepted: 02 June 2019

ABSTRACT: Benzoxazoles and their derivatives have exerted anti-cancer and anti-inflammatory (immunomodulatory) potential due to their anti-proliferative effect on the cells. These molecules are DNA basebioisosteres, therefore, their mechanism of action could be by mimicking the structures of the DNA bases and halting the DNA polymerization processes. Based on their anti-proliferative effect, in our study we aimed to decipher the potential anti-inflammatory activities of unique bisbenzoxazole derivatives in vitro on mammalian macrophages. Being able to manipulate the inflammatory function of macrophages would enable the regulation of the immune response against danger stimuli. This would enable us better prognosis against different types of the diseases ranging from autoimmune disorders to cancer. Our results support the stark anti-inflammatory potential of bisbenzoxazole derivatives RHE 241 and RHE 248 in vitro on the LPS activated mammalian macrophages. After further delineation of their mechanism of action in vitro and their in vivo potency, these molecules could be utilized as potent anti-inflammatory medicines.

KEYWORDS: Bisbenzoxazole; inflammation; macrophage; anti-inflammatory; anti-proliferative agents.

\section{INTRODUCTION}

Macrophages are white blood cells found in the mammalian tissues. During their development process through hematopoiesis, they are produced in the bone marrow as monocytes. While leaving the blood stream the monocytes differentiate into macrophages in the tissues and strengthen the defense against invaders microorganisms [1-7]. Macrophages are part of the innate immune system since they recognize the pathogen associated patterns or other danger molecules at the early stages of infection and respond accordingly [1-7]. Through their cytokine production as well as antigen presenting capabilities they are also involved in adaptive immune system reactions [1-14]. When microbes invade or infect our body, macrophages are attracted to the region through signaling molecules known as chemokines and initiate an inflammatory reaction while eliminating the danger associated molecule through phagocytosis[1-14]. If there is a lack of tissue resident macrophages, then the monocytes in the blood stream and other phagocytic cells are stimulated to leave the blood stream. Then, they get into the tissue by squeezing through the endothelial cells on the walls of the blood vessels [1-14]. After phagocytosis, macrophages degrade the pathogens by releasing destructive enzymes of the lysozyme into the phagosome (then becomes phagolysozyme)[1-14]. Macrophages can present these degraded molecules of the pathogen on their surface on MHC class II molecule to the T helper cells to further activate the adaptive branch of the immune system and start a more robust reaction against the invading pathogen [1-14]. Moreover, macrophages contribute to the homeostasis of the body by clearing apoptotic, necrotic cells and other cell debris as well as by secreting growth factors and other signaling molecules (cytokines) in order to regulate tissue inflammation and after eliminating the danger wound healing processes [1-14]. Inflammation is a complex process that involves complex cascade of signals that leads changes $\mathrm{f}$ in the function of the tissue resident cells as well as the immune system cells in order to start a proper response to the danger and to eliminate; this danger can be either a tissue injury or tumorous cells or an infectious agent [15-29]. During inflammation besides antigen presentation and phagocytosis, macrophage

How to cite this article: Ayaz F, Isse QA, Kheeree R, Ersan RH, Algül Ö. Immunomodulatory and immunostimulatory effects of some bisbenzoxazole derivatives on lipopolysaccharide stimulated mammalian macrophages. J Res Pharm. 2019; $23(5)$ : $944-951$. 
regulate the immune responses through production of various cytokines and other growth factors that affect the entire inflammation process e.g. initiation, maintenance and resolution of inflammation[1-14].

They can get activated and deactivated during the inflammatory response depending on the signaling milieu. Activation signals include cytokines (interferon gamma, granulocyte-monocyte colony stimulating factor, interleukin 1 beta, interleukin 6 and tumor necrosis factor alpha), bacterial lipopolysaccharide, extracellular matrix proteins, and other chemical mediators[1-14]. Inhibition of inflammation by the removal or deactivation of inflammatory mediators and cells enables tissue repair and wound healing processes to start and anti-inflammatory cytokines (interleukin 10 and transforming growth factor beta) play a crucial role at this step [1-14].

Immunomodulatory molecules are new generation therapeutics that can prevent excessive inflammatory responses or shape the type and strength of the immune responses. Finding anti- inflammatory molecules would enable us preventing damaging inflammation in case of autoimmune or inflammatory diseases whereas pro-inflammatory or immune-stimulatory molecules have potential to be used as adjuvant candidates or immune booster agent [15-29].

Previous studies support anti-proliferative and apoptotic roles of benzoxazole containing compounds [30-45]. These derivatives have been studied for their anti-cancer and anti-inflammatory potentials [30-45]. Most of the studies rely on superficial analysis of their apoptotic and anti-proliferative activities [30-45]. In the light of those studies we designed and synthesized a series of unique bisbenzoxazole derivatives. After inital screening two strong candidates were further analyzed for their anti-inflammatory activities. We deciphered the immunomodulatory and immune-stimulatory roles of bisbenzoxazole based RHE 241 and 248 molecules on macrophages. These unique molecules can be used as anti-inflammatory drug agents in inflammatory disorders as well as autoimmune diseases.

\section{RESULTS}

\subsection{RHE 241 and 248 treatments did not change the percentage of live macrophage cells after 24 hours}

Both of our reagents had anti-proliferative effect on macrophage cell line (Figure 1). The cell viability of RAW 264.7 macrophage cells was 100\% in the presence of RHE 241 and RHE 248 at concentrations of 50, 75 and $100 \mathrm{ug} / \mathrm{ml}$ with or without polysaccharide LPS for 24 hours. There was no difference between the two chemicals effects in terms of anti-proliferative effect on the macrophages (Figure 1).
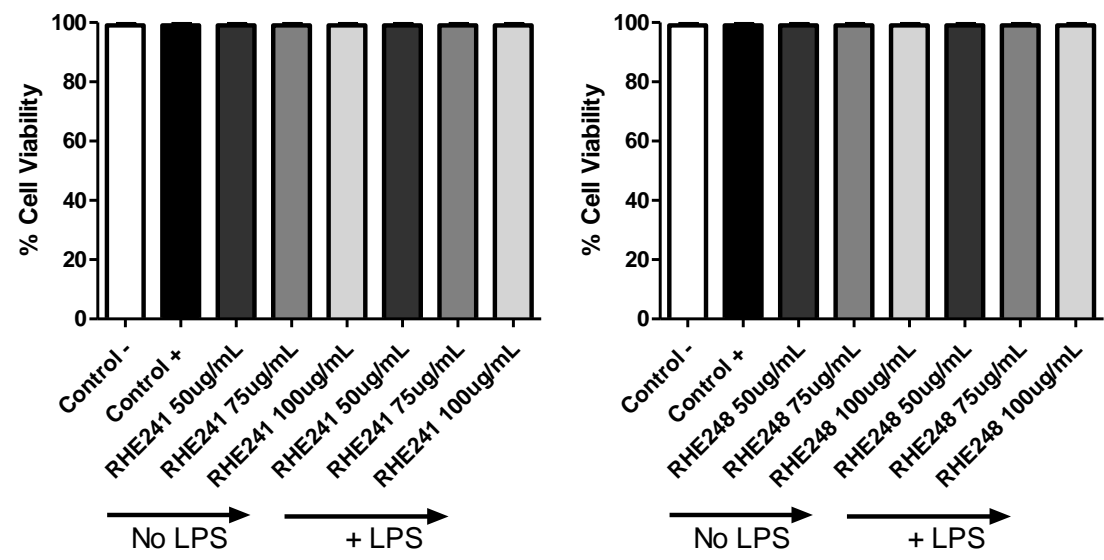

Figure 1. Percentage of viable cells were counted with Trypan blue staining after stimulating RAW macrophage cells for 24 hours with 50, 75 and $100 \mathrm{ug} / \mathrm{ml}$ of RHE241 and RHE 248. 1X1066ells/ml cell concentration was used and DMSO was used for negative control, $1 \mathrm{ug} / \mathrm{ml}$ of LPS and DMSO was used for positive control and 50, 75 and $100 \mathrm{ug} / \mathrm{ml}$ of the chemical dissolved in DMSO with or without LPS were applied to the cells. Student $\mathrm{t}$ test was applied for statistical analysis, $\mathrm{p}<0.0001 \mathrm{~N}=9$.

\subsection{RHE 241 and 248 abrogated the Tumor Necrosis Factor Alpha (TNFa) secretion by LPS induced macrophages}

TNFa is pro-inflammatory cytokine which is produced by different immune cells e.g. macrophages. Raw 264.7 cells were treated with RHE 241 and RHE 248 at concentrations of 50, 75 and $100 \mathrm{ug} / \mathrm{ml}$ with or 
without LPS for 24 hours to observe the change in TNFa secretion. Cells in the positive control wells which were treated with $1 \mathrm{ug} / \mathrm{ml}$ of LPS and DMSO produced a substantial amount of TNFa compared to untreated control negative wells. Our chemicals with varying concentrations did not induce TNFa secretion by themselves which indicates that they lack immunostimulatory role (Figure 2). Whereas, in the presence of LPS danger signal our chemicals caused a significant decrease in TNFa production compared to the positive control wells (Figure 2).Therefore, our reagents had immunomodulatory effect on macrophages by acting as strong anti-inflammatory agents (Figure 2).
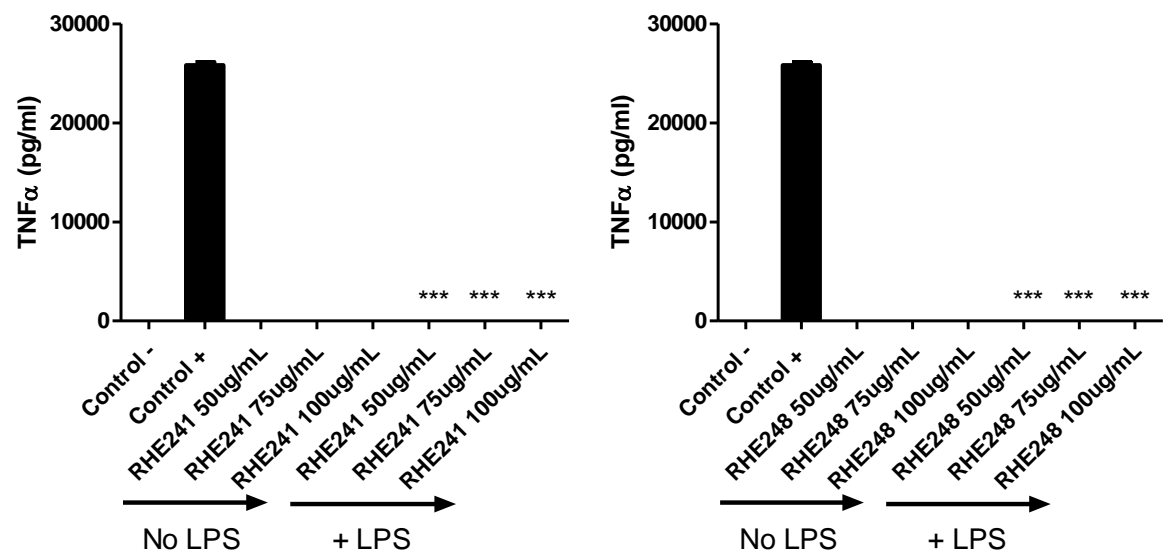

Figure 2.TNFa ELISA for the supernatants of RAW macrophage cells stimulated for 24 hours with 50, 75 and $100 \mathrm{ug} / \mathrm{ml}$ of RHE241 and 248. 1X106 cells/ml cell concentration was used and DMSO was used for negative control, $1 \mathrm{ug} / \mathrm{ml}$ of LPS and DMSO was used for positive control and 50, 75 and $100 \mathrm{ug} / \mathrm{ml}$ of the chemical dissolved in DMSO with or without LPS were applied to the cells. Student $t$ test was applied for statistical analysis, $\mathrm{p}<0.0001 \mathrm{~N}=9$.

\subsection{RHE 241 and 248 abrogated the Interleukin 1 Beta (IL-1b) secretion by LPS induced macrophages}

Raw 264.7 cells treated with RHE 241 and RHE 248 at concentrations of 50, 75 and $100 \mathrm{ug} / \mathrm{ml}$ with / without LPS for 24 hours in order to observe the (IL-1 $\beta$ ) production. We added $5 \mathrm{mM}$ freshly prepared ATP solution into the each well 2 hours before harvesting to induce IL1 $\beta$ secretion. As shown in the figure 3 we were able to induce IL1 $\beta$ production by LPS stimulated macrophages in the positive control wells. Similar to their effect on TNFa secretion, our chemicals did not induce macrophages to produce IL1 $\beta$ by themselves (Figure 3).Moreover, there was substantial and complete knockout of IL1 $\beta$ production by LPS stimulated macrophages in the presence of our reagents (Figure 3).
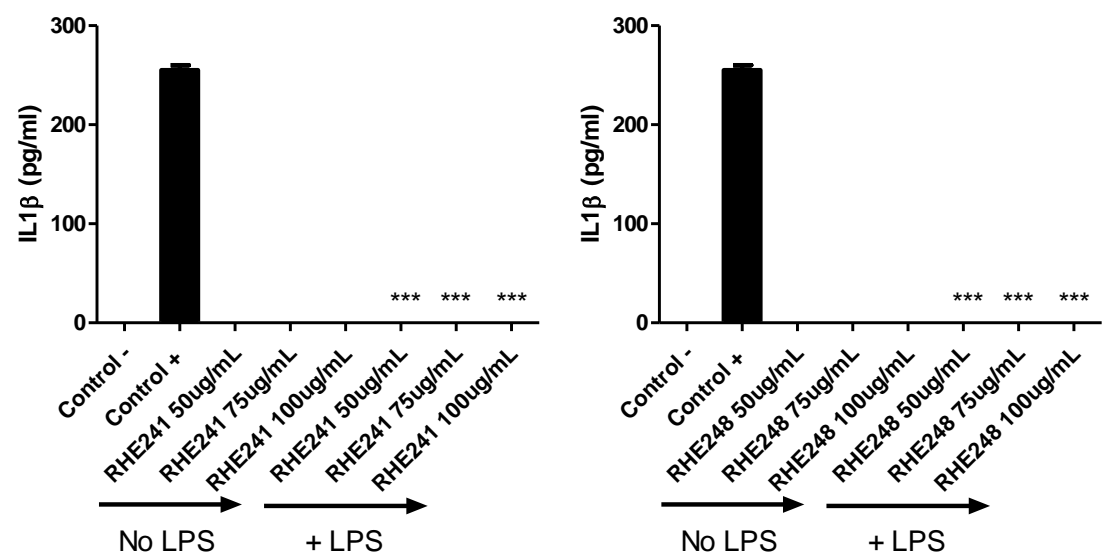

Figure 3. IL1b ELISA for the supernatants of RAW macrophage cells stimulated for 24 hours with 50, 75 and $100 \mathrm{ug} / \mathrm{ml}$ of RHE 241 and 248. 1X106 cells/ml cell concentration was used and DMSO was used for negative control, $1 \mathrm{ug} / \mathrm{ml}$ of LPS and DMSO was used for positive control and 50, 75 and $100 \mathrm{ug} / \mathrm{ml}$ of the chemicals dissolved in DMSO with or without LPS were applied to the cells. Student $t$ test was applied for statistical analysis, $\mathrm{p}<0.0001 \mathrm{~N}=9$. 


\subsection{RHE 241 induced the Interleukin 6 (IL-6)secretion by non-stimulated macrophages while both RHE 241} and RHE 248 were suppressing its production by LPS induced macrophages

Raw 264.7 cell lines were treated with RHE 241 and RHE 248 at concentrations of 50, 75 and $100 \mathrm{ug} / \mathrm{ml}$ with / without LPS for 24 hours in order to observe the (IL-6) secretion. As shown in figure 4, only LPS induction of macrophages leads to a substantial amount of IL6 production. RHE 241 had immunostimulatory role in the production of IL6, since in the absence of danger signal it was able to cause IL6 production levels similar to those of control positive wells (Figure 4a). Whereas in the presence of LPS it acted as antiinflammatory reagent since it lead to a significant decrease in the production of IL6 compared to positive control (Figure 4a). RHE 248 was lacking this immunostimulatory effect on IL6 production by macrophages whereas it also acted as a strong anti-inflammatory reagent on the LPS stimulated macrophages (Figure 4b).
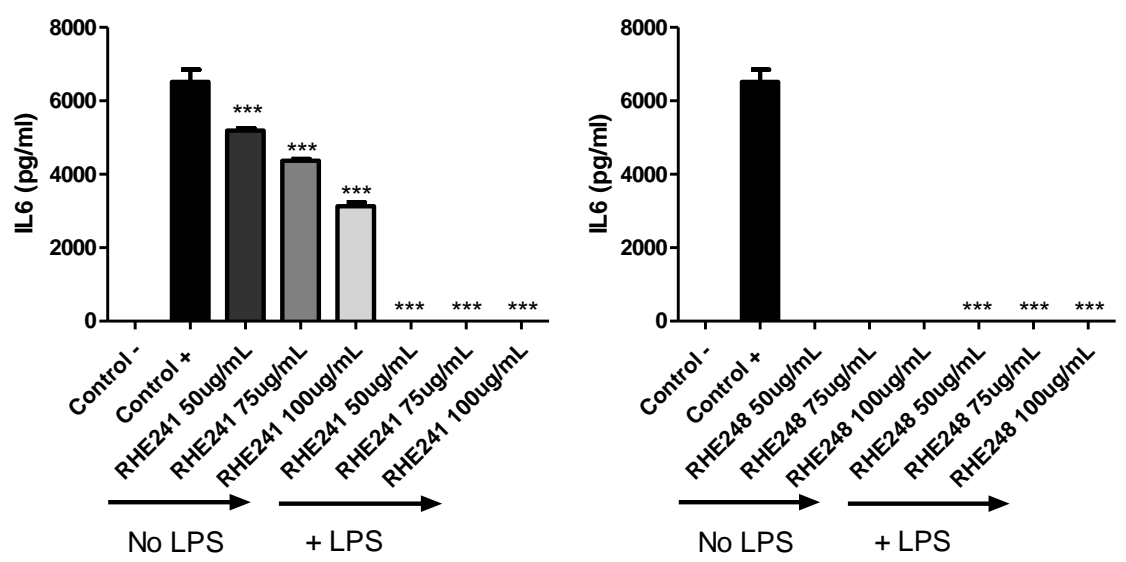

Figure 4. IL6 ELISA for the supernatants of RAW macrophage cells stimulated for 24 hours with 50, 75 and $100 \mathrm{ug} / \mathrm{ml}$ of RHE 241 and 248. 1X106 cells/ml cell concentration was used and DMSO was used for negative control, $1 \mathrm{ug} / \mathrm{ml}$ of LPS and DMSO was used for positive control and 50, 75 and $100 \mathrm{ug} / \mathrm{ml}$ of the chemicals dissolved in DMSO with or without LPS were applied to the cells. Student $t$ test was applied for statistical analysis, $\mathrm{p}<0.0001 \mathrm{~N}=9$.

\section{DISCUSSION}

Macrophages are immune cells with variety of functions. Their major role in the production of different kinds of cytokines gives them unique properties. Macrophages can produce both pro-inflammatory and antiinflammatory cytokines depending on the needs of the tissue or the whole organism [1-14]. They are essential against the invaders such as bacteria and virus by sensing the pathogen associated molecular patterns. Upon sensing these danger molecules they start secreting cytokines to prepare the immune system against the invaders and eventually eliminate them[1-14].These pro-inflammatory cytokines enable other immune cells proper migration into the endangered tissue, their activation and after eradication of the danger their suppression and wound healing is enhanced by anti-inflammatory cytokines produced by macrophages[114].

Non-steroid based anti-inflammatory drug candidates have gathered attention due to their diminished side effects on the patients [30-45]. Benzoxazole derivatives are studied for this purpose extensively [30-45]. There have been studies indicating their anti-proliferative function [30-45]. This anti-proliferative function is partly due to their similarities to DNA bases [30-45]. Benxoxazole derivatives probably interfere the DNA synthesis machinery and prevent cell proliferation in this way [30-45]. Due to their strong biological activities benzoxazole derivatives have been suggested as anti-cancer and anti-inflammatory drugs [30-45]. In order to generate the most active compound with the least side effects, new benzoxazole derivatives should be designed and characterized. In this way, a library of molecules can be generated to use in drug development against cancer as well as inflammatory and autoimmune disorders.

For this purpose we designed a series of bisbenzoxazole derivatives. After initial screening of their biological activities, two molecules with the highest anti-proliferative activities were further assessed for their anti-inflammatory potentials in vitro. The objective of the study was assessing the possible immunostimulatory and immunomodulatory effects of bisbenzoxazole based RHE 241 and 248 molecules on the unstimulated and LPS stimulated macrophages. Our results overlapped with the previous findings and these unique 
bisbenzoxazole derivatives significantly and substantially decreased the pro-inflammatory cytokine production by activated macrophages [30-45]. This effect was so stark that the cytokine production was completely knockedout in the presence of our molecules.

Immunomodulatory molecules, synthetic or natural, are capable of modifying the immune responses [15-29]. There are conventional and novel immunomodulators like adjuvants, cytokines, hormones, glucocorticoids, host defense peptides, microbial products, toll like receptors, synthetic compounds, probiotics, nutrients, vitamins, minerals, herbs, polysaccharides, vaccines [15-29]. Immunomodulatory molecules mimic anti-inflammatory molecules and alter duration, potency and types of immune response by blocking the action of the inflammatory pathways to prevent further tissue destruction [15-29]. Inhibition of pro-inflammatory cytokines' (TNFa, IL1b, IL-6) production in our study strongly suggests that the bisbenzoxazole based RHE 241 and 248 molecules have potent anti-inflammatory activity on macrophages.

Moreover, RHE 241 was able to induce IL6 production even in the absence of the danger signal LPS whereas it suppressed the production of this cytokine when there was LPS stimulation compared to positive control cells. RHE 241 held its anti-inflammatory potential and can furthermore support tissue renewal and wound healing by inducing IL6 production in non-inflammatory environments which lack danger signals. This unique ability increases its potential to prevent and heal the tissue destruction in autoimmune or chronic inflammatory diseases.

\section{CONCLUSION}

Overall, bisbenzoxazole derivatives RHE 241 and RHE 248 decreased the pro-inflammatory TNFa, IL1 $\beta$ and IL6 production by the LPS stimulated macrophages in vitro. Compared to the positive control groups, these derivatives completely knocked out the production of the pro-inflammatory cytokines. These molecules hold a great potential to be used as anti-inflammatory drugs against inflammatory diseases in which macrophages play a major role in the induction of the inflammation. These diseases include autoimmune diseases such as Multiple Sclerosis and Rhematoid Arthiritis, and chronic inflammatory diseases like Chron's disease [15-29]. Currently we are further investigating their molecular mechanism of action at cellular level and in vivo efficacies.

\section{MATERIALS AND METHODS}

\subsection{Chemistry}

The target compounds showed in Figure 5 were obtained by reacting the starting material the 4-chloro2-aminophenol (1) or 5-nitro-2-aminophenol (3) with 2,2'-thiodiacetic acid(2) or malonic acid(4) for 13-15 hours to give bis ((5-chlorobenzo[d]oxazol-2-yl)methyl) sulfane (RHE 241) (CAS Number: 66000-12-2) and bis(6nitrobenzo[d]oxazol-2-yl)methane (RHE 248) (CAS Number: 1713164-75-0) in 70-75\% yield. Although these two compounds are commercially available, the compounds have been synthesized by us in this study. All experimental procedures and results are presented in the supplementary section. The structure of compounds RHE 241 and RHE 248 were confirmed by IR, ${ }^{1} \mathrm{H}-\mathrm{NMR}$, and ${ }^{13} \mathrm{C}-\mathrm{NMR}$ spectroscopy. IR spectra of the compounds showed an absorption band at $1560,1666 \mathrm{~cm}^{-1}$ indicating the presence of $\mathrm{C}=\mathrm{N}$ of oxazole ring functionality. ${ }^{1} \mathrm{H}-\mathrm{NMR}$ spectra of the compounds showed single signals at 4.03 and $2.23 \mathrm{ppm}$ corresponding to $-\mathrm{CH}_{2}$ - and $-\mathrm{CH}_{2}-\mathrm{S}-\mathrm{CH}_{2}$ - linker groups. ${ }^{13} \mathrm{C}-\mathrm{NMR}$ spectrum of the compounds showed the characteristic signals of carbon atoms of linker group at 24.1 and 28.5 ppm respectively (Supplementary Figures).

\subsection{In vitro cell activation studies}

\subsubsection{Cell culture}

RAW 264.7 cells were grown in Roswell Park Memorial Institute media (RPMI 1640) media with \%10 fetal bovine serum, $\% 1$ antibiotics $(100 \mu \mathrm{g} / \mathrm{ml}$ penicillin and $100 \mu \mathrm{g} / \mathrm{ml}$ streptomycin) and sodium pyruvate. Cells were incubated in $37^{\circ} \mathrm{C} \% 5 \mathrm{CO}_{2}$ incubator. Cell media was refreshed once in every 4 days until they reach confluency to be used in the experiments.

\subsubsection{RHE 241 and 248 and lipopolysachharide (LPS) stimulation to mimic danger signal}

RAW 264.7 cells were put in $10^{6}$ cells/well concentration in $1 \mathrm{ml}$ fresh complete RPMI as described above into 24-well plates, then they were rested overnight in $37^{\circ} \mathrm{C} 5 \% \mathrm{CO}_{2}$ incubator. We tested 50,75 and $100 \mathrm{ug} / \mathrm{ml}$ RHE 241 and 248 effect on RAW 264.7 cells in the presence and absence of inflammatory stimulator LPS. $1 \mu 1$ of LPS (1mg/mL, Enzo Life Sciences, Salmonella minnesota R595) was put into $1 \mathrm{~mL}$ media of overnight rested 
cells. The same volume of DMSO was put into control negative and LPS only control wells. Then cells were treated with the RHE 241 and 248 and LPS for 24 hours in $37^{\circ} \mathrm{C} 5 \%$ incubator. Afterwards supernatants of each well were collected into eppendorf tubes and centrifuged at 2000RPM to get rid of any cellular debris, then supernatants were transferred into fresh eppendorf tubes and kept at $-80^{\circ} \mathrm{C}$ before further examination. All experimental conditions were tested as a triplicate. In order to measure IL1 $\beta$ levels, similar experimental set up was started and $2 \mathrm{mM}$ freshly prepared ATP (Fischer Science) was put into the each well of the cells two hours before collecting the supernatants.

A<smiles></smiles>

B<smiles></smiles>

Figure 5: Synthesis method of Compounds. A) Compound RHE 241 B) Compound RHE 248.

\subsubsection{TNFa, IL6 and IL1 $\beta$ ELISAs}

TNFa, IL6 and IL1 $\beta$ production was measured by using enzyme-linked immunosorbent assay (ELISA). For each cytokine type (BD Biosciences, CA, USA) ELISA kit was used by following the manufacturer's instructions. Maxisorb 96 well plate (Krackeler) was first coated overnight with hamster anti-mouse cytokine $(0.5 \mu \mathrm{g} / \mathrm{mL}$ in bicarbonate buffer $\mathrm{pH}=9.5,100 \mu \mathrm{L} /$ well $)$. After getting rid of the solution the plate was washed 3 times with $0.05 \%$ Tween 20 PBS. Then plate was blocked with $200 \mu \mathrm{L}$ blocking buffer (1\% BSA PBS) in each well after 3 hours of incubation at room temperature. After washing the plate 3 times samples were put as 100 $\mu \mathrm{L}$ into each well and incubated overnight at $4{ }^{\circ} \mathrm{C}$. After washing the plate 3 times $100 \mu \mathrm{L}$ biotin human antimouse cytokine $(0.5 \mu \mathrm{g} / \mathrm{mL} \mathrm{10 \%} \mathrm{FBS} \mathrm{PBS'te)} \mathrm{was} \mathrm{put} \mathrm{into} \mathrm{each} \mathrm{well} \mathrm{and} \mathrm{plate} \mathrm{was} \mathrm{incubated} \mathrm{at} \mathrm{room}$ temperature for 2 hours. After discarding the solution the plate was washed 3 times and $100 \mu \mathrm{L}$ of Streptavidin HRP solution was put into each well and plate was incubated for 2 hours at room temperature. Then plate was washed 3 times and $100 \mu \mathrm{L}$ TMB substrate (BD OptEIA) was put into each well and $50 \mu \mathrm{L}$ of $1 \mathrm{M}$ sulfuric acid was used to stop the reaction and absorbance was measured at $450 \mathrm{~nm}$. By using known concentrations of each cytokine's as standard the concentration of TNFa, IL1 $\beta$ and IL6 in each sample was calculated.

Acknowledgements: This study was supported by 2017-2-AP-4-2506 BAP Project of Mersin University and The Scientific and Technological Research Council of Turkey (TUBITAK, Grant Number: 115S190). Our group greatly appreciates the material support of Prof.Dr. Juan Anguita from CICBiogune.

Author contributions: Concept - F.A.,Ö.A.; Design - F.A.,Ö.A.; Supervision - F.A., Ö.A.; Materials F.A., Q.A.I., R.K., Ö.A., R.H.E.; Data Collection and/or Processing - F.A., Q.A.I., R.K., Ö.A., R.H.E..; Analysis and/or Interpretation F.A., Q.A.I., R.K., Ö.A., R.H.E.; Literature Search - F.A., Q.A.I., R.K., Ö.A., R.H.E.; Writing - F.A., Q.A.I., R.K., Ö.A., R.H.E.; Critical Reviews - F.A., Q.A.I., R.K., Ö.A., R.H.E.

Conflict of interest statement: "The authors declared no conflict of interest" in the manuscript.

\section{Appendix A. Supplementary Material}

Supplementary Material related to this article can be accessed at https://doi.org/10.35333/jrp.2019.41. 


\section{REFERENCES}

[1] Arango DG, Descoteaux A. Macrophage cytokines: Involvement in immunity and infectious diseases. Front Immuno. 2014; 491(5): 491-502. [CrossRef]

[2] Murray RZ, Stow JL. Cytokine secretion in macrophages: SNAREs, Rabs, and membrane trafficking. Front Immunol. 2014; 5: 538-546. [CrossRef]

[3] Kawagishi C, Kurosaka K, Watanabe N, Kobayashi Y. Cytokine production by macrophages in association with phagocytosis of etoposide-treated P388 cells in vitro and in vivo. Biochim Biophys Acta. 2001; 1541(3): $221-230$. [CrossRef]

[4] Cavaillon JM. Cytokines and macrophages. Biomed Pharmacother. 1994; 48(10): 445-453. [CrossRef]

[5] Scull CM, Hays WD, Fischer TH. Macrophage proinflammatory cytokine secretion is enhanced following interaction with autologous platelets. J Inflam. 2010; 7(53): 1-9. [CrossRef]

[6] Berghaus LJ, Moore JN, Hurley DJ, Vandenplas ML, Fortes BP, Wolfert MA, Boons GJ. Innate immune responses of primary murine macrophage-lineage cells and RAW 264.7 cells to ligands of Toll-like receptors 2, 3, and 4. Comp Immunol Microbiol Infect Dis. 2010; 33(5): 443-454. [CrossRef]

[7] Schmitz F, Mages J, Heit A, Lang R, Wagner H. Transcriptional activation induced in macrophages by Toll-like receptor (TLR) ligands: From expression profiling to a model of TLR signaling. Eur J Immunol. 2004; 34(10): 28632873. [CrossRef]

[8] Soromou LW, Zhang Z, Li R, Chen N, Guo W, Huo M, Guan S, Lu J, Deng X. Regulation of inflammatory cytokines in lipopolysaccharide-stimulated RAW 264.7 murine macrophage by 7-O-methyl-naringenin. Molecules. 2012; 17(3): 3574-3585. [CrossRef]

[9] Gasparini C, Foxwell BM, Feldmann M. RelB/p50 regulates TNF production in LPS-stimulated dendritic cells and macrophages.Cytokine. 2013; 61(3): 736-740. [CrossRef]

[10] Parameswaran N, Patial S. Tumor necrosis factor-a signaling in macrophages. Crit Rev Eukaryot Gene Expr. 2010; 20(2): 87-103.

[11] Lopez CG, Brough D. Understanding the mechanism of IL-1 $\beta$ secretion. Cytokine Growth Factor Rev. 2011; 22(4): 189-195. [CrossRef]

[12] Manderson AP, Kay JG, Hammond LA, Brown DL, Stow JL. Subcompartments of the macrophage recycling endosome direct the differential secretion of IL-6 and TNFa. J Cell Biol. 2007; 178(1): 57-69. [CrossRef]

[13] Grossi G, Di BM, Roma G, Ballabeni V, Tognolini M, Barocelli E. 1,8-Naphthyridines v. novel N-substituted 5-aminoN,N-diethyl-9- isopropyl [1,2,4]triazolo[4,3-a] [1,8]naphthyridine-6-carboxamides, as potent anti-inflammatory and/or analgesic agents completely devoid of acute gastrolesivity. Eur J Med Chem. 2005; 40(2): 155-165. [CrossRef]

[14] Dianzani C, Collino M, Gallicchio M, Di Braccio M, Roma G, Fantozzi R. Effects of anti-inflammatory [1, 2, 4] triazolo[4, 3-a] [1, 8] naphthyridine derivatives on human stimulated PMN and endothelial cells: an in vitro study. J Inflamm. 2006; 3(1): 4-13. [CrossRef]

[15] Broide DH. Immunomodulation of Allergic Disease. Annu Rev Med. 2009; 60: 279-291. [CrossRef]

[16] Iwalewa EO, McGaw LJ, Naidoo V, Eloff JN. Inflammation: the foundation of diseases and disorders. A review of phytomedicines of South African origin used to treat pain and inflammatory condition. Afr J Biotechnol. 2007; 6(25): 2868-2885. [CrossRef]

[17] Ayaz F. Ruthenium pyridyl thiocyanate complex increased the production of pro-inflammatory TNFa and IL1 $\beta$ cytokines by the LPS stimulated mammalian macrophages in vitro. Mol Biol Rep. 2018; 45(6): $2307-2312$. [CrossRef]

[18] Ayaz F, Yuzer A, Ince M. Immunostimulatory effect of Zinc Phthalocyanine derivatives on macrophages based on the pro-inflammatory TNFa and IL1 $\beta$ cytokine production levels. Toxicol in Vitro. 2018; 53: 172-177. [CrossRef]

[19] Hancock REW, Nijnik A, Philpott DJ. Modulating immunity as a therapy for bacterial infections. Nat Rev Microbiol. 2012; 10: 243-254. [CrossRef]

[20] Kaufmann T,Simon HU. Targeting disease by immunomodulation. Cell Death Differ. 2015; 22(2): 185-186. [CrossRef]

[21] Julier Z, Park AJ, Briquez PS, Martino MM. Promoting Tissue Regeneration by Modulating the Immune System. Acta Biomaterialia. 2017; 53: 13-28. [CrossRef]

[22] Khalil DN, Smith EL, Brentjens RJ, Wolchok JD. The future of cancer treatment: immunomodulation, CARs and combination immunotherapy. Nat Rev Clin Oncol. 2016; 13(5): 273-290. [CrossRef] 
[23] Tan TT, Coussens LM. Humoral immunity, inflammation and cancer. Curr Opin Immunol. 2007; 19(2): $209-216$. [CrossRef]

[24] Daniel CS, Ira M. Oncology meets immunity. Immunity, 2013; 39(1): 1-10. [CrossRef]

[25] Guevara PJA, Turk MJ, Wolchok JD, Houghton AN. Immunity to cancer through immune recognition of altered self: Studies with melanoma, advances in cancer research. Academic Press, 2003; 90: 157-177. [CrossRef]

[26] Valdés RR, Benítez AA. Nutrition and immunity in cancer. Br J Nutr. 2007; 98(S1): 127-132. [CrossRef]

[27] Grivennikov SI, Greten FR, Karin M. Immunity, inflammation, and cancer. Cell. 2010; 140(6): 883-899. [CrossRef]

[28] Rakoff N S. Why Cancer and Inflammation? Yale J Biol Med. 2006; 79(3-4): 123-130.

[29] Coussens LM, Werb Z. Inflammation and cancer. Nature. 2002; 420(6917): 860-867.

[30] Algul O, Kaessler A, Apcin Y, Yilmaz A, Jose J. Comparative studies on conventional and microwave synthesis of some benzimidazole, benzothiazole and indole derivatives and testing on inhibition of hyaluronidase. Molecules, 2008; 13(4): 736-748.

[31] Ayaz F, Kheeree R, Isse Q, Ersan R, Algul O. DNA Base Bioisosteres, Bis-benzoxazoles, Exert anti-proliferative effect on human prostate and breast cancer cells. JOTSCA. 2018, 5(3): 1145-1152. [CrossRef]

[32] Kaessler A, Algul O, Jose J. A microplate based screening of benzimidazole derivatives on hyaluronidase inhibition at pH 7 and 3.5. Lett Drug Des Discov. 2007; 4(8): 562-569. [CrossRef]

[33] Algul O, Duran N. Activity of bisbenzimidazole derivatives against Staphylococcus epidermidis. Asian J Chem. 2007; 19(4): 3145-3151.

[34] Kandeel MM, Abdelall EKA, Abd El Hamid MK, Abdelgawad MA, Philoppes JN. Synthesis and in vitro antitumor activity of new benzothiazole and benzoxazole derivatives. J Chem Pharm Res. 2013; 5(8): 16-21.

[35] Shitha G, Amma VK, Kamala B, Babu G, Biju CR. In-silico docking investigation, synthesis and in vitro anticancer study of benzoxazole derivatives. J Drug Deliv. Technol. 2014; 4(6): 122-126. [CrossRef]

[36] Hedidi M, Bentabed AG, Derdour A, Roisnel T, Dorcet V, Chevallier F, Picot L, Thiery V, Mongin F. Synthesis of $\mathrm{C}, \mathrm{N}$ '-linked bis-heterocycles using a deprotometalation-iodination-N-arylation sequence and evaluation of their antiproliferative activity in melanoma cells. Bioorg Med Chem. 2014; 22(13): 3498-3507. [CrossRef]

[37] Gülcan HO, Ünlü S, Banoğlu E, Şahin MF, Küpeli E, Yeşilada E. Synthesis of new 4-(5-Chloro-2-oxo-3H-benzoxazol3-yl)butanamide derivatives and their analgesic and anti-inflammatory properties. Turk J Chem. 2003; 27: 467-476.

[38] Koksal M, Gokhan N, Kupeli E, Erdogan H. Analgesic and antiinflammatory activities of some new mannich bases of 5-nitro-2-benzoxazolinones. Arch Pharm Res. 2007; 30(4): 419-424.

[39] Potashman M, Bready J, Coxon A, DeMelfi T. Design, synthesis, and evaluation of orally active benzimidazoles and benzoxazoles as vascular endothelial growth factor-2 receptor tyrosine kinase inhibitors. J Med Chem. 2007; 50(18): 4351-4373. [CrossRef]

[40] Xue C, Rafalski M, Roderick J, Eyermann CJ, Mousa S, Olson RE, DeGrado WF. Design, synthesis and in vitro activities of a series of benzimidazole/benzoxazole glycoprotein IIb/IIIa inhibitors. Bioorg Med Chem Let. 1996; 6(3): 339-344. [CrossRef]

[41] Sun LQ, Chen J, Takaki K, Johnson G. Design and synthesis of benzoxazole derivatives as novel melatoninergic ligands. Bioorg Med Chem Lett. 2004; 14(5): 1197-2000. [CrossRef]

[42] Kumar JMR, Reynolds MB, Kerwin SM. Synthesis and evaluation of anticancer benzoxazoles and benzimidazoles related to UK-1. Bioorg Med Chem. 2002; 10(12): 3997-4004.

[43] Klimesova V, Koci JK, Waisser J, Kaustova U. Synthesis and preliminary evaluation of benzimidazole derivatives as antimicrobial agents. Eur J Med Chem. 2009; 44(5): 2286-93. [CrossRef]

[44] Kakkar S, Tahlan S, Lim SM, Ramasamy K, Mani V, Shah SAA, Narasimhan B. Benzoxazole derivatives: design, synthesis and biological evaluation. Chem Cent J. 2018; 12(1):92. [CrossRef]

[45] Chandni J, Neeru C, Meena N, Gita S. Synthesis and Biological activity of organophosphates phenoxy derivatives derived from 2-mercapto benzoxazole. Phosphorus Sulfur Silicon Relat Elem. 2014; 189(11): 1699-1705. [CrossRef] 